\title{
WhatsApp and Its Potential to Develop Communication Skills among University Students
}

\author{
https://doi.org/10.3991/ijim.v15i23.27243
}

\author{
Suraya Morsidi ${ }^{1}$, Norazrena Abu Samah ${ }^{1(\bowtie)}$, Khairul Anuar Abdul Rahman², \\ Zakiah Mohamad Ashari ${ }^{1}$, Nurul Farhana Jumaat ${ }^{1}$, Abdul Halim Abdullah ${ }^{1}$ \\ ${ }^{1}$ Universiti Teknologi Malaysia, Johor Bahru, Malaysia \\ ${ }^{2}$ Universiti Tun Hussein Onn Malaysia, Parit Raja, Malaysia \\ norazrena@utm.my
}

\begin{abstract}
Excellent communication skills among graduates are very crucial for their future and career development. WhatsApp application is seen to have the potential to develop these skills since it has robust functions and features, easy to use, and free. However, there are still issues in implementing this application as a tool in developing communication skills by utilizing this application for educational purposes among UTM students. Hence, this study was aiming to investigate the level of WhatsApp usage in education, the level of communication skills by utilizing WhatsApp for educational purposes among students, and their correlations. Student's perception of using WhatsApp in education was also investigated. This study was based on quantitative research conducted using a survey design, where online questionnaires were distributed randomly among 400 UTM students based on simple random method. Findings showed that there is a high level of WhatsApp usage in education among UTM students and also a high level of communication skills by utilizing this application for educational purposes among UTM students. It was supported by a strong positive linear correlation that existed between these two variables. Students also showed positive perceptions of utilizing WhatsApp in education to develop their communication skills. Therefore, lecturers and students are encouraged to utilize WhatsApp application in education as it can help in fortifying communication skills among students who later become competent graduates that can meet the demand from the industries.
\end{abstract}

Keywords-WhatsApp application, communication tool, learning tool, collaboration tool, communication skills

\section{Introduction}

The current changes in technology development have improved in many ways and rapidly. This advancement of technology has helped many industries to evolve, including in education settings. [1] mentioned the importance of educational technology in teaching is due to its use for information and communication technologies. Furthermore said, the students and teachers see the effectiveness of instructional techniques, 
such as using the internet for distance learning. The student prefers modern technology introduced in teaching and learning, where this advanced equipment, tools, and technology contribute to effectiveness in students learning and interactivity [2].

The implementation of technology in education has helped the teaching and learning process become more manageable, productive, and innovative. [2] also mentioned that technology is part of the curriculum, where it provides an instructional delivery system, aiding instructions, and improve the learning process entirely. Nowadays, students, especially in higher education, own a smartphone to ease their daily routine. The production of smartphones has enhanced and improved the utilization of Mobile Instant Messaging (MIM) technology [3]. WhatsApp is one of the well-known applications generally used in the education setting [4]. It is also known as mobile communication services as it provides a platform to communicate with each other either privately or in the group via text chatting, voice note, and video call through the internet connection. The spectacular functions and features provided by WhatsApp has become the reason why this technology is preferable among students to communicate with their instructors and peers [5]. It is the most popular MIM application, with 1.6 million active users globally [6]. Numerous studies have mentioned the advantage of using WhatsApp application in the education setting [7-14].

Therefore, this technology is seen to have the possibility of enhancing communication skills among students. Lacking in communication skills have been an issue for graduates to secure a job in working industries. The increasing rate of unemployment graduates left a great deal for the institutes. Communication skills are very crucial as non-technical skills, abstract but highly demanding skills in the industry. Academic excellence alone is not enough to fulfil market demand and expectations [15]. Communication skills are crucial in professional life. Students were presumed to possess this skill due to the increasing demands of this skill from employers. Nevertheless, employers expect their employees to possessed excellent communication skills along with hard skills to ensure the employees can contribute to the company's success [16].

Malaysian Qualification Framework Second Edition (MQF 2nd Edition) introduced a framework that aims to improve the skills and potential of learners to quality talent and citizens, regardless of sector and domestic needs. MQF is Malaysia's stance on the qualifications and quality of the education system. MQF is a tool that creates and categorizes the skills from elements that are nationally accepted and standard against global best practices and making clear the academic level, learning results from all the study areas, and student-academic load from credit system based. Five clusters of learning outcomes that represent every level in MQF introduced. However, this study only focuses on group three of the clusters, which covers the learning outcome and application context of functional work skills for higher education levels. The functional work skills focused in this study are communication skills. Hence, this study serves the purpose (i) to investigate the level of WhatsApp usage in education in terms of utilizing it as a tool for collaboration, learning, and communication among UTM students, (ii) to investigate the level of communication skills by utilizing WhatsApp for educational purposes among UTM students, and (iii) to investigate the correlation between the level of WhatsApp usage in education and the level of communication skills by utilizing WhatsApp application for educational purposes among UTM students. 


\section{$2 \quad$ Literature review}

\subsection{The issue in utilizing WhatsApp application in education}

The use of WhatsApp has escalated in education these recent years. However, some issues faced in utilizing WhatsApp in higher education have occurred. The problems related to the utilization of WhatsApp application in education is relating to the use of WhatsApp application as the tool for communication, learning, and collaboration. The first point is the issue of using WhatsApp application as a tool for communication. There is a high intensity of number increasing upon the studies related to the use of WhatsApp in mobile devices. However, the studies focused on WhatsApp functionalities and effects as an alternative communication system to improve the educational process in the university by teaching virtual tutoring is still scarcely any [13]. The lack of a comprehensive understanding of using WhatsApp application in teaching and learning despite the growing of MIM applications in the market. The presence of technology needed to attract students' attention to education [17]. Besides, the lack of guidelines on how to use this messaging tools in higher education exists in teaching practices, so do the perceptions of students and teachers' attitudes towards the use of messaging tools in teaching and learning [18]. WhatsApp is the least exploit of its functionalities in the mobile phone. It is sometimes uneasy and burdensome to type in the small mobile screen, and the screen resolutions itself is contributing to the difficulties [19].

The second point is the issue of using WhatsApp application as a tool for learning. Students gave adverse opinions relating to WhatsApp usage, especially on the timing of some posts, as well as the redundant thread of messages posted in the group [20-23]. Most students used WhatsApp primarily for the social and personal purpose in daily life but limited usage for educational purposes even though WhatsApp is a regularly used application for interaction among students [24]. Educators find it is not comfortable to utilize WhatsApp into the teaching and learning since they are more comfortable to use computers instead. WhatsApp is the least preferable tool for teaching and learning even it provides the standard and alternative platform to deliver the instructional materials and activities [5].

The third point is the issue of using WhatsApp application as a tool for collaboration. The use of WhatsApp application as a platform for online group discussion could outperform the conventional ways of face-to-face discussion teaching in the same course are still uncertain [7]. The effect of using WhatsApp as self-initiated group discussion among the students has not yet been explored [25].

\subsection{The issue of lacking in communication skills among graduates}

In this globalization era, the lack of communication skills caused the problem of employability [26-28]. Five out of hundreds of graduates' candidates passed the interview for employment due to lacking in communication skills [16]. This cause the policy involvement for higher education in developing country like Malaysia has increased due to the issue relating to graduates' employability and unemployment. The gap in the availability of labour market demand for graduates has caused several problems 
in graduates' standards due to lacking of communication skills [29]. Even though graduates are excellent academically, but they are still failed to put themselves in the working industries. The dissatisfaction of employers nowadays is caused by the quality of the incompetent graduates that did not meet the current job market's requirements. The rapid changes in the technology and expectation in industrial requirement are the apparent weakness to the graduates that cannot keep up with the changing pace [30].

Besides the graduates' attitude, lacking in communication skills, self-confidence, and technology skills also contributed to the growing number of unemployed graduates in Malaysia, regardless of the increase of job vacancies in the industry because it is not matching up with the employer's expectation [30]. Sometimes, students are uncomfortable to speak in the class because of low self-confidence and ideas to express themselves. Meanwhile, some students have plenty of ideas to discuss, but they have difficulties in elaborating and expressing themselves verbally. Some students are excellent in speaking but struggle to impart their ideas and points [31]. Despite many activities organized by the university, but yet, the communication skills among students are still low [32]. According to [33], attention is needed to focus on the fact that students lack the confidence to communicate with others. It is found that students lack in communication skills, especially while doing group discussion and activities.

\section{Methodology}

\subsection{Research design}

This study deployed a quantitative research approaches where non-experimental Survey Design is used as the blueprint for the research design. According to [34], survey design is a nonexperimental design that produces a description of a quantitative or numeric of trends, point of view, or stance of a population by experimenting with the populations' sample. Survey design permits to summarize the characteristic of a different group or to measure respondent attitude and opinion towards some issue. Hence, the cross-sectional survey design is deployed in this study to determine the present insights or behaviors of a group in the designated point and time.

\subsection{Research procedure}

This research was carried out in four phases. First, in the analysis phase, the literature review regarding the issue of WhatsApp usage in education was disclosed, including elements that enhance communication skills are analyzed based on the MQF standard instrument and other previous research. Second, in design and development phase, the research instrument designed, developed, pilot-tested, and modified for its validity and reliability during the pilot study. A pilot study was conducted before implementing it to collect the actual data. The questionnaire was adapted and edited suitable to the research objectives from several previous studies, and related questions were also taken from the MQF standard instrument to construct the items. Once done, the result analyzed from the pilot study will determine the validity and reliability of the research instrument. Instrument's revision will be done after the pilot study, if necessary. Preservation of the 
quality of this study is very crucial. Therefore, the questions construct will not consist of anything that is considered sensitive to the respondents.

Third, during the implementation phase, the actual survey distributed randomly among the samples in the population using a convenient sampling technique. The questionnaires created using Google Form and distributed online using the auto-generated link through the WhatsApp application. It is purposely to distribute the survey online to control error in sampling. It is to ensure that the target samples are among the WhatsApp users. The survey link will be broadcasted from time to time until it reaches the number of desired samples size in this study. Therefore, data collection monitored until responses reach a $100 \%$ response rate from respondents. Follow up made on the data collection process to increase responses from samples. The questionnaire submitted by respondents collected using excel spreadsheets through Google Form and transferred into SPSS software for detailed data analysis. Respondent selections are random among UTM students. They will be informed about the objectives of distributing the survey before they were asked to answer the questionnaire. Distribution of the questionnaires will not be in any risking and harming situation to maintain the ethical value of this study.

Lastly, during the evaluation phase, data from the survey collected and transferred into SPSS software for further analysis. Data analyzed based on the suitable analysis test from the designated research questions - the result from the data analysis reported as the findings and elaborated further in the discussion. Based on the discussion, the suggestion made to improve the study in the future. Lastly, the conclusion made to wrap up the study.

\subsection{Sample and population}

The population in this study consists of students from Universiti Teknologi Malaysia. The number of students' population (N) in UTM is around 28200 students. The target samples were narrowed down to the postgraduate and undergraduate students. The sample size (n) is about ten students for the pilot study to test the instrument's reliability after instrument's validation from the experts. During the actual survey, 400 samples are selected randomly using a convenient sampling method. This amount of samples were referred to Krejcie and Morgan table [35]. The use of a convenient sampling method in this study is to help in selecting samples from a group of students in the population based on the student's availability and can be found easily. Convenience sampling is affordable, accessible, and the samples are available at any time [36].

\subsection{Instrument}

In this study, the instrument used in collecting data was the questionnaire that divided into three parts comprising 25 4-point Likert scale items used in this studyStrongly Disagree (1), Disagree (2), Agree (3), and Strongly Agree (4). Only four scales were used in this study to ensure proper data analysis process. According to [37], respondents' bias formed from the desires to please the researcher can be controlled by removing the mid-point scale of uncertainty. In this study, the respondents 
for the pilot study were selected randomly using a convenient sampling method. A total of 10 respondents were involved in this pilot study to representing the samples from the actual research. The reliability of the instrument is tested using Cronbach's $\alpha$. According to [38], Cronbach's $\alpha$ is a standard test used to determine the internal instrument consistency. Cronbach's $\alpha$ will give a value between 0 and 1 . The acceptance value for reliability is when alpha, $\alpha$ is equal to 0.7 or higher. Only Part B and Part $\mathrm{C}$ undergo the test. Table 1 shows the pilot-tested of the instrument's result based on Cronbach's Alpha $(\alpha)$ test.

Table 1. Reliability test result

\begin{tabular}{|l|c|c|}
\hline \multicolumn{1}{|c|}{ Construct } & \multicolumn{1}{c|}{$\begin{array}{c}\text { Cronbach's Alpha } \\
\text { (n= 400) }\end{array}$} & $\begin{array}{c}\text { Number } \\
\text { of Items }\end{array}$ \\
\hline Part B: Students' Level of WhatsApp Usage in Education \\
\hline a. WhatsApp: A tool for Communication & 0.978 & 5 \\
\hline b. WhatsApp: A tool for Collaboration & 0.901 & 7 \\
\hline c. WhatsApp: A tool for Learning & 0.924 & 7 \\
\hline Part C: Students' Level of Communication Skills by Utilizing WhatsApp for Educational Purposes \\
\hline $\begin{array}{l}\text { a. Level of Communication Skills by Utilizing } \\
\text { WhatsApp for Educational Purposes }\end{array}$ & 0.728 & 7 \\
\hline
\end{tabular}

\section{$4 \quad$ Results and findings}

The current changes in technology development have improved in many ways and rapidly. This advancement of technology has helped many industries to evolve, including in education settings. [1] mentioned the importance of educational technology in teaching is due to its use for information and communication technologies. Furthermore said, the students and teachers see the effectiveness of instructional techniques, such as using the internet for distance learning. The student prefers modern technology introduced in teaching and learning, where this advanced equipment, tools, and technology contribute to effectiveness in students learning and interactivity [2-39].

The first research question requires an analysis of the level of WhatsApp usage in education among UTM students. Most of the students have a high level (97.2\%) of WhatsApp usage in education. Meanwhile, some of the students have a moderate level $(2.8 \%)$ of using WhatsApp in education, but there are no students categorized under a low level of utilizing WhatsApp in education. Therefore, these results show that most of UTM students have applied WhatsApp intensively in education as a tool for communication, collaboration, and learning.

The second research question requires an analysis of the level of communication skills by utilizing the WhatsApp application for educational purposes among UTM students. Most students have a high level $(56.0 \%)$ of communication skills by utilizing WhatsApp for educational purposes. Meanwhile, some of the students have a moderate level (40.5\%) of communication skills by utilizing WhatsApp for educational purposes, and some students are categorized under a low level (3.5\%) of communication skills by 
utilizing WhatsApp for educational purposes. Therefore, these results show that most of UTM students have developed a high level of communication skills by utilizing WhatsApp for educational purposes.

The third research question requires an analysis of the existence of a correlation between the level of WhatsApp usage in education and the level of communication skills by utilizing WhatsApp application for educational purposes among UTM students. Therefore, the spearman correlation test is used to investigate the existence of the two variables. The results showed a strong, positive, and significant correlation that exists between the level of WhatsApp usage in education and the level of communication skills by utilizing WhatsApp for educational purposes among UTM students $(\mathrm{r}=0.618, \mathrm{n}=400, \mathrm{p}<0.01$, two tails $)$.

\section{$5 \quad$ Discussions}

\subsection{Discussion on the level of WhatsApp usage in education among UTM students}

Based on the findings, most of UTM students have a high level (97.2\%) of WhatsApp usage in education. WhatsApp is an example of the technology that commonly used in smartphones that have changed the way people communicate [22, 40]. Besides, almost all students have WhatsApp installed in their digital devices. Utilizing mobile instant messaging in smartphones enables teaching and learning to be interactively implemented outside the classroom environment using a less restrictive learning environment. They can communicate, learn, and collaborate by accessing a wide range of online material quickly in real-time after lectures [12, 41-45].

WhatsApp is introduced as a new educational tool that supports the relationship between teachers and students [46]. WhatsApp has become the most favored application utilized as one of the tools used for teaching and learning in education and students usually used WhatsApp to communicate about their interest of several topics with each other [12]. The used of WhatsApp application for academic purposes, especially for students in higher education where they usually interact and communicate using this application for the both educational and non-educational matter. This tool has become popular rapidly and becoming essential to our lives and education [10, 14].

According to [22], the WhatsApp application will not take long to affect the learning surroundings. WhatsApp used as an online learning platform where it is a medium for communication and collaboration. Teachers and students can used the WhatsApp application current updated features in conducting the teaching and learning process creatively [47]. Moreover, [19] mentioned that WhatsApp application allowed students to deal with new information, create social networks, offered idea-sharing, and develop understanding and learning mutually in informal forms. [10] emphasized the desires of students' learning community to use WhatsApp application as an educational tool to enhance communication skills.

Therefore, these results show that the majority of UTM students have applied WhatsApp intensively in education as a tool for communication, collaboration, and learning, which, according to [48], developing technology has evolved in the teaching 
profession from teacher-centered to student-centered learning. The impact of utilizing WhatsApp on teaching and learning has grown each year rapidly. It also has a positive effect on academic achievement, especially for students who learn in groups. Student-centered learning taught students the skills to identify issues, data collection, and analyze, making conclusions and results reporting through digital tools to complete the task. The institutions should utilize WhatsApp to perceive its usefulness, especially for collaboration, communication, and learning.

\subsection{Discussion on the level of communication skills by utilizing WhatsApp for educational purposes among UTM students}

Based on the findings, most of UTM students have a high level (56.0\%) of communication skills by utilizing WhatsApp in education. Students utilized WhatsApp for educational purposes in many ways to develop their communication skills. Communication skills consist of listening, speaking, reading, and writing skills [49]. Students mostly used WhatsApp to enhance their listening skills using audio and video files. It is essential to create productive and pleasant listening practices to improve listening skills. Listening activities can be done by sending and playing audio and video files through WhatsApp or links of the audio sources and then making discussions about the audio or video contents in the group. WhatsApp application is capable of delivering messages and sharing information instantly, which could help to support extensive listening activities to improve listening skills [50].

Further, students mostly used WhatsApp to enhance their speaking skills through voice notes and video calls. Students can enhance their speaking skills by using the voice note feature and share it in the group or with their friend personally for practising purposes. Students might practise speaking skills using video calls with their friends. Moreover, students showed significant improvements in speaking skills because they can discuss verbally with the use of voice notes and video calls [51]. Besides, UTM students mostly used WhatsApp to enhance their reading skills through reading documents and any given resource links. According to [11] study, reading skills can be improved by reading chatting discussed in WhatsApp either by simple texting, through documents or links shared in WhatsApp. It helps students to practice their vocabulary. Further, the skill developed reflecting on the reading activities made, such as reading through documents or educational links shared in the group, is to improve their reading comprehension. Through this sharing, students can read adequately, understand, and paraphrase the articles [52].

Moreover, students mostly used WhatsApp to enhance their writing skills using text messaging. According to [4], WhatsApp application can improve writing skills through learning activities such as chatting using text messaging in the application. Besides, [52] mentioned that activities through WhatsApp enhanced students' motivation to improve their writing skills. It is a platform for groups to practice their written communication. Texting activity in groups can help poor learning students to learn from their advanced peers. Meanwhile, students mostly used WhatsApp to develop their confidence when communicating with others. WhatsApp offered interactive and real-time discussion which encourage the teachers and students to elaborate on the 
topic deeper and openly. Students feel comfortable to share their answer and presented it in the group confidently. It encourages engagement, and at the same time, it enhances students' confidence level in communicating with others [53].

Nevertheless, students mostly used WhatsApp to help them learn from their colleague's mistakes. Mentioned by [31], online discussion using WhatsApp enhances virtual interaction between teachers and students. It helps to facilitates and solves difficulties in learning. Besides, the discussion process encourages students to communicate where they can learn from each others' mistakes done during the process of learning, which will be corrected by the teacher [54]. Students prefer to use WhatsApp to improve their speaking, reading, writing, and listening skills. Their view on the critical use of WhatsApp application not only to improved communication skills but also to boost up their confidence, motivation, and creativity [55].

\subsection{Discussion on the correlation between the level of WhatsApp usage in education and the level of communication skills by utilizing WhatsApp for educational purposes among UTM students}

Based on the findings, there was a strong, positive, and significant correlation that exists between the level of WhatsApp usage in education and the level of communication skills by utilizing WhatsApp application for educational purposes among UTM students. With the advancement of technology, students gained the essential communication skills required in 21st-century learning [47, 54]. By utilizing WhatsApp application to its maximum potential and the ability to extend the learning in different situations and environment, it helps students to use the technology without boundaries and limits [47]. Even though communication skills cannot be taught, however, it can be enhanced through proper training with the help of technology such as WhatsApp [16]. UTM students used the WhatsApp application as a tool for learning in education and agreed it has contributed to the development of their communication skills. According to [52], WhatsApp acted as a learning tool where language can be practiced freely and used in real communication. Chatting and learning at the same time through WhatsApp application makes learning more fun, exciting, and motivating. Students learned new things from sharing new words and experiences. This situation helps in developing the essential elements in communication skills. Besides, WhatsApp as a learning tool improved student's academic achievement, functional work skills, and enhanced positive attitudes towards learning compared to traditional classroom learning. WhatsApp features such as text messaging, video call, and voice messages utilized to teach students in enhancing their writing, vocabulary, speaking, listening, and reading skills. It also helps in developing research skills, technology literacy skills, and communication skills [57].

Moreover, UTM students used the WhatsApp application as a tool for communication in education that contributed to the development of their communication skills. According to [58], when WhatsApp is used as a communication tool, it impacts students' speaking skills positively, especially for the development of their communication skills. Besides, the majority of the students believe that their communication skills and relationship development with others have improved through communication using 
the WhatsApp application [59]. If students used the WhatsApp application correctly, it will influence their awareness and, at the same time, improved different skills, not only communication skills, but also increased their language proficiency. It also helps in increasing students' self-esteem because utilizing WhatsApp in the right ways will affect students' communication skills [60]. It adequately proves that the WhatsApp application appears to be a powerful tool used for communication as it uses mobile technologies to enhance the process of communication skills [61].

Nevertheless, UTM students used the WhatsApp application as a tool for collaboration in education that contributed to the development of their communication skills. According to [1], students are using WhatsApp application as an educational technology tool for virtual classrooms, where it helps in creating a collaboration platform for online discussions. It helps students to improve their language and communication skills. Besides, communication skills developed as students used information technology and networking skills to collaborate in groups such offered in WhatsApp application [62]. WhatsApp provides a collaboration medium that allows students to work together in a team. Interaction in the group among teachers and students by developing cooperation to complete the given tasks [63]. Such activities have promoted WhatsApp as a tool to develop communication skills as well as other soft skills [53]. This finding proves that the WhatsApp application is undoubtedly used as an educational tool for communication, learning and collaboration in education that can develop communication skills among UTM students [64].

\section{Conclusion}

In conclusion, all the research questions of this study have been acknowledged and answered. There was four objectives position in this study. The first research objective was to investigate the level of WhatsApp usage in education among UTM students. There are 16 items in this section, and it is statistically proven that UTM students have a high level of WhatsApp usage used in education. The findings showed that this application is highly used for educational purposes as a tool for communication, collaboration, and learning among the students. Meanwhile, the second research objective was to investigate the level of communication skills by utilizing WhatsApp for educational purposes among UTM students. In this section, it consists of 7 items. It is statistically proven that UTM students have a high level of communication skills by utilizing WhatsApp application for educational purposes. From the findings, the students agreed that the application enhanced their communication skills. Finally, the last research objective was to investigate whether there is any correlation exist between the level of WhatsApp usage in education and the level of communication skills by utilizing WhatsApp application for educational purposes among UTM students. The result of this study showed that there is a correlation that exists between these two variables, where it is statistically proven to exist in positive, strong, and significant correlation. Therefore, this study has proven that the utilization of WhatsApp as a tool for communication, collaboration, and learning in education can develop communication skills among students of UTM. 


\section{$7 \quad$ References}

[1] Lu-akyol, P. K. Ğ. (2018). Using Educational Technology Tools to Improve Language and Communication Skills of ESL Students. Novitas-ROYAL (Research on Youth and Language), 4(November), 225-241.

[2] Raja, R., \& Nagasubramani, P. C. (2018). Impact of Modern Technology in Education. Journal of Applied and Advanced Research, 3(1), 165. https://doi.org/10.21839/jaar.2018. v3iS1.165

[3] Rashid, C. A. (2017). An Evaluation of Mobile Instant Messaging Applications' Preferences: Case of Kurdistan Region of Iraq. International Journal of Social Sciences \& Educational Studies, 3(4), 20-35. https://doi.org/10.23918/ijsses.v3i4p20

[4] Sharma, S. (2019). Smartphone Based Language Learning through Mobile Apps. International Journal of Recent Technology and Engineering, 8(4), 8040-8043. https://doi. org/10.35940/ijrte.D6783.118419

[5] So, S. (2016). Mobile Instant Messaging Support for Teaching and Learning in Higher Education. Elsevier, 31, 32-42. https://doi.org/10.1016/j.iheduc.2016.06.001

[6] Clements, J. (2020). Most Popular Global Mobile Messaging Apps. Retrieved from https:// www.statista.com/statistics/258749/most-popular-global-mobile-messenger-apps/

[7] Augustine, S. E., \& Nwaizugbu, N. Q. (2018). WhatsApp Utilization and Academic Performance of Computer in Education Trainee Teachers in University of Port-Harcourt. International Journal of Education, 6(5), 15-25.

[8] Hayashi, Y. (2019). Multiple Pedagogical Conversational Agents to Support Learner-Learner Collaborative Learning: Effects of Splitting Suggestion Types. Cognitive Systems Research, 54, 246-257. https://doi.org/10.1016/j.cogsys.2018.04.005

[9] Ibrahim, A. A. (2019). Research Trends On The Use Of WhatsApp In Education : A Content Analysis Social \& Behavioural Sciences AIMC 2017 Asia International Multidisciplinary Conference RESEARCH TRENDS ON THE USE OF WHATSAPP IN EDUCATION : A CONTENT ANALYSIS, (April). https://doi.org/10.15405/epsbs.2018.05.11

[10] Igbafe, E. C., \& Anyanwu, C. N. (2018). WhatsApp at Tertiary Education Institutions in Nigeria: The Dichotomy of Academic Disruption or Academic Performance Enhancer? Africology: The Journal of Pan African Studies, 12(2).

[11] La Hanisi, A., Risdiany, R., Dwi Utami, Y., \& Sulisworo, D. (2018). The Use of WhatsApp in Collaborative Learning to Improve English Teaching and Learning Process. International Journal of Research Studies in Educational Technology, 7(1). https://doi.org/10.5861/ ijrset.2018.3004

[12] Mbukusa, N. R. (2018). Perceptions of students' on the Use of WhatsApp in Teaching Methods of English as Second Language at the University of Namibia. Journal of Curriculum and Teaching, 7(2), 112. https://doi.org/10.5430/jct.v7n2p112

[13] Román Graván, P., Ballesteros Regaña, C., \& Noguera, M. D. D. (2018). Academic WhatsApp Groups as Alternative Communication and Motivation Systems in Higher Education. Espacios, 39(10).

[14] Rosenberg, H., \& Asterhan, C. S. C. (2018). "WhatsApp, Teacher?" - Student Perspectives on Teacher-Student WhatsApp Interactions in Secondary Schools. Journal of Information Technology Education: Research, 17, 205-226. https://doi.org/10.28945/4081

[15] Seetha, N. (2014). Are Soft skills Important in the Workplace? - A Preliminary Investigation in Malaysia. International Journal of Academic Research in Business and Social Sciences, 4(4), 44-56. https://doi.org/10.6007/IJARBSS/v4-i4/751

[16] Mahajan, R. (2015). The Key Role of Communication Skills in the Life of Professionals. Journal of Humanities and Social Science, 20(12), 36-39. https://doi. org/10.9790/0837-201223639 
[17] Tang, Y., \& Hew, K. F. (2017). Is Mobile Instant Messaging (MIM) Useful in Education? Examining its Technological, Pedagogical, and Social Affordances. Educational Research Review, 21(November 2018), 85-104. https://doi.org/10.1016/j.edurev.2017.05.001

[18] Parkes, M., \& Adlington, R. (2017). Using WhatsApp in EFL Instruction with Saudi Arabian University Students. Arab World English Journal (AWEJ), 8(December), 68-84. https://doi. org/10.24093/awej/vol8no4.5

[19] Andujar, A. (2016). Benefits of Mobile Instant Messaging to Develop ESL Writing. Elsevier, 62, 63-76. https://doi.org/10.1016/j.system.2016.07.004

[20] Aicha, A. B. (2014). The Impact of WhatsApp Mobile Social Learning on the Achievement and Attitudes of Female Students Compared With Face to Face Learning in the Classroom. European Scientific Journal, 10(22), 116-136. Retrieved from http://eujournal.org/index. php/esj/article/viewFile/3909/3700

[21] Bouhnik, D., \& Deshen, M. (2014). WhatsApp Goes to School: Mobile Instant Messaging between Teachers and Students. Journal of Information Technology Education, 13(23), 217-231. https://doi.org/10.1021/ic034568v

[22] Cetinkaya, L. (2017). The Impact of WhatsApp Use on Success in Education Process. International Review of Research in Open and Distance Learning, 18(7), 59-74. https://doi. org/10.19173/irrodl.v18i7.3279

[23] Thomson, D. A. (2014). Convenience or Nuisance?: The 'WhatsApp' Dilemma. Pharmaceutical Journal, 280(7499), 507. https://doi.org/10.1016/j.sbspro.2014.10.278

[24] Gasaymeh, A. M. (2017). University Students' use of WhatsApp and their Perceptions Regarding its Possible Integration into their Education. Global Journal, 17(1).

[25] Qiao, Y., Tang, Y., \& Hew, K. F. (2018). Student Cognitive Presence in Small Group Collaboration Facilitated by Mobile Instant Messaging. International Journal of Educational Technology and Learning, 2(1), 14-24. https://doi.org/10.20448/2003.21.14.24

[26] Md-Ali, R., Shaffie, F., \& Mohd Yusof, F. (2016). Understandings and Conceptions of Soft Skills for Educators in Public Universities. In The European Proceedings of Social \& Behavioural Sciences, 694-701. https://doi.org/10.15405/epsbs.2016.08.98

[27] Musa, M., \& Sin, S. H. (2016). Soft Skills and its Impact on the Marketability if UUM Graduates. International Journal of Organizational \& Business Execellence, 1(2), 1-10. https:// doi.org/10.5430/ijhe.v3n4p64

[28] Nusrat, M. (2018). Soft Skills for Sustainable Employment: Does it really Matter? International Journal of Management and Economics Invention, 04(07). https://doi.org/10.31142/ ijmei/v4i7.03

[29] Yusof, N., \& Jamaluddin, Z. (2015). Graduate employability and preparedness: A case study of University of Malaysia Perlis (UNIMAP), Malaysia. Malaysian Journal of Society and Space 11, 11(11), 129-143. Retrieved from http://www.ukm.my/geografia/images/ upload/13x.fullgeo-okt15-nooriah-edam.pdf

[30] Suhail, P., Ahmad, E., \& Ainah, M. J. A. (2015). Soft Skills Construct For Architecture Graduate In Accordance With Industries Requirement. International Journal of Humanities, Arts and Social Sciences, 1(3). https://doi.org/10.20469/ijhss.20002-3

[31] Mistar, I., \& Embi, M. A. (2016). Students' Perception on the Use of WhatsApp As a Learning Tool in Esl Classroom. Journal of Education and Social Sciences, 4, 96-104. Retrieved from $\underline{\mathrm{http}}$ ///jesoc.com/wp-content/uploads/2016/08/Edu-76.pdf

[32] Malik, A., Setiawan, A., Suhandi, A., Permanasari, A., Dirgantara, Y., Yuniarti, H., ... Hermita, N. (2018). Enhancing Communication Skills of Pre-service Physics Teacher through HOT Lab Related to Electric Circuit. Journal of Physics: Conference Series, 953(1), 0-8. https://doi.org/10.1088/1742-6596/953/1/012017 
[33] Rathee, R., \& Rajain, P. (2018). Role of Communication Skills for Management Students. Global Journal of Commerce \& Management Perspective, 7(1), 41-46. https://doi. org/10.24105/gjemp.7.1.1809

[34] Creswell, J. W. (2014). Research Design 4th Edition. Qualitative, Quantitative, and Mixed Methods Approaches.

[35] Krejcie, R. V., \& Morgan, D. W. (1970). Determining Sample Size for Research Activities. Educational and Psychological Measurement, 30, 607-610. https://doi.org/10.1261/ rna.2763111

[36] Etikan, I. (2016). Comparison of Convenience Sampling and Purposive Sampling. American Journal of Theoretical and Applied Statistics, 5(1), 1. https://doi.org/10.11648/j. ajtas.20160501.11

[37] Garland, R. (1991). The Mid-point on a Rating Scale: Is it Desirable. Marketing Bulletin, 2(1), 66-70.

[38] Heale, R., \& Twycross, A. (2015). Validity and Reliability in Quantitative Studies. Evidence-Based Nursing, 18(3), 66-67. https://doi.org/10.1136/eb-2015-102129

[39] Mun, S. H., Abdullah, A. H., Mokhtar, M., Ali, D. F., Jumaat, N. F., Ashari, Z. M., Abu Samah, N., \& Abdul Rahman, K. A. (2019). Active Learning Using Digital Smart Board to Enhance Primary School Students' Learning. International Journal of Interactive Mobile Technologies, 13(7), 4-16. https://doi.org/10.3991/ijim.v13i07.10654

[40] Noor Azuan, H., Nor Liza, A., Rosmah, M. I., \& Hawati, J. (2015). WhatsApp Messenger Application among Business Students in Malaysia - An Exploration. Jurnal Personalia Pelajar, 18(2), 97-105.

[41] Barhoumi, C. (2015). The Effectiveness of WhatsApp Mobile Learning Activities Guided by Activity Theory on Students' Knowledge Management. Contemporary Educational Technology, 6(3), 221-238. https://doi.org/10.30935/cedtech/6151

[42] Nitza, D., \& Roman, Y. (2016). WhatsApp Messaging: Achievements and Success in Academia. International Journal of Higher Education, 5(4), 255-261. https://doi.org/10.5430/ ijhe.v5n4p255

[43] Sam, P. (2016). Learning beyond the Classroom through WhatsApp: An Informal Channel to Motivate Learners to stay Connected. Asian Journal of Research in Social Sciences and Humanitie, Vol. 6, No(January), 1826-1833. https://doi.org/10.5958/2249-7315. $\underline{2016.00910 .2}$

[44] Selva Kumar, V., Yang Lian, T., \& Vasudevan, H. (2016). UNiKL RCMP Undergraduates Perception on using WhatsApp as a Tool for Mandarin Language Teaching and Learning. In Language Education and Civilisation International Conference.

[45] Wang, Y., \& Liu, C. (2017). Cultivate Mindfulness: A Case Study of Mindful Learning in an English as a Foreign Language Classroom. IAFOR Journal of Education, 18(7). https://doi. org/10.22492/ije.4.2.08

[46] Kufre, P., \& Abe, E. (2017). Effectiveness of WhatsApp as a Collaborative Tool for Learning among Undergraduate Students in University of Uyo, Akwa Ibom state. International Journal of Advanced Education and Research, 2(5), 43-46.

[47] Annamalai, N. (2018). How do We Know What is Happening in WhatsApp: A Case Study Investigating Pre-service Teachers' Online Activity. Malaysian Journal of Learning and Instruction, 15(2), 207-225. https://doi.org/10.32890/mjli2018.15.2.8

[48] Sayan, H. (2016). Affecting Higher Students Learning Activity By Using WhatsApp. European Journal of Research and Reflection in Educational Sciences, 4(3), 88-93. Retrieved from www.idpublications.org

[49] Moore, E. (2018). Communication skills. CIM Magazine, 9(1), 63-66. 
[50] Fauzi, I., \& Angkasawati, P. (2019). the Use of Listening Logs Through WhatsApp in Improving Listening Comprehension of Efl Students. JOALL (Journal of Applied Linguistics \& Literature), 4(1), 13-26. https://doi.org/10.33369/joall.v4i1.6773

[51] Aiman, N., Mohd Jafre, B., Aini, N., \& Hussain, B. (2017). Enhancing English Proficiency Among Dkm1S3 Students: Improving Communicative Skills Using WhatsApp Application. Politeknik \& Kolej Komuniti Journal of Social Sciences and Humanities, 149-162.

[52] Ahmed, S. T. S. (2019). WhatsApp and Learn English: a Study of the Effectiveness of WhatsApp in Developing Reading and Writing Skills in English. ELS Journal on Interdisciplinary Studies on Humanities, 2(2), 148-156. https://doi.org/10.34050/els-jish.v2i2.6419

[53] Setyowati, Y. (2019). Let's Listen Through WhatsApp: An energizing listening exercise in EFL Class. Journal of Physics: Conference Series, 1179(1). https://doi. org/10.1088/1742-6596/1179/1/012052

[54] Ta'amneh, M. A. A. A. (2017). The Effect of Using WhatsApp Messenger in Learning English Language among University Students. International Research in Education, 5(1), 143. https://doi.org/10.5296/ire.v5i1.10801

[55] Alsulami, S. (2016). The Effects of Technology on Learning English as a Foreign Language Among Female EFL Students at Effatt College : An Exploratory Study. CSCanada Studies in Literature and Langauuge, 12(4), 1-16. https://doi.org/10.1054/midw.2001.0253

[56] Sugito, S., Susilowati, S. M. E., Hartono, H., \& Supartono, S. (2017). Enhancing Students' Communication Skills Through Problem Posing and Presentation. International Journal of Evaluation and Research in Education (IJERE), 6(1), 17. https://doi.org/10.11591/ijere. $\underline{\mathrm{v} 6 \mathrm{i} 1.6342}$

[57] Shariffuddin, S. A., Shaaidi, W. R. W., \& Hashim, S. M. (2017). International Journal of Advanced and Applied Sciences Social networks as instructional tools beyond a classroom. International Journal of Advanced and Applied Sciences, 4(12), 185-192. https://doi. org/10.21833/ijaas.2017.012.033

[58] Noyan, E., \& Kocoglu, Z. (2019). Developing EFL Writing Skills through WhatsApp Dialogue Journaling. Advances in Language and Literary Studies, 10(2), 38. https://doi. org/10.7575/aiac.alls.v.10n.2p.38

[59] Bakar, D. A., Rashid, A. A., \& Aziz, N. A. (2014). Impacts of Instant Messaging on Communications and Relationships among Youths in Malaysia. In International Conference on Economics, Education and Humanities (pp. 10-11).

[60] Wong, D. H., \& Phang, C. (2017). Effect of Social Media on Human Interpersonal Communication : A Review. Open International Journal of Informatics (OIJI), 5(2), 1-6.

[61] Roberto, B., Encarnacion, B., Montserrat, M., \& Ana, F. (2017). Communication Tool to Improve the Collaborative Work Using Emerging Mobile Technologies. Advances in Information Science and Computer Engineering, 12(5), 101-109.

[62] Muste, D. (2016). The Role of Communication Skills in Teaching Process, 430-434. https:// doi.org/10.15405/epsbs.2016.12.52

[63] Jumaat, N. F., Ahmad, N., Abu Samah, N., Ashari, Z. M., Ali, D. F., \& Abdullah, A. H. (2019). Facebook as a Platform of Social Interactions for Meaningful Learning. International Journal of Emerging Technologies in Learning, 14(4), 151-159. https://doi.org/10.3991/ijet. $\underline{\mathrm{v} 14 \mathrm{i} 04.9363}$

[64] Mohd Yunos, M. A. A., Atan, N. A., Haruzuan Mohamad Said, M. N., Mokhtar, M., \& Abu Samah, N. (2017). Collaborative Learning in Authentic Environment Apps to Promote Preschool Basic Scientific Process Skills. International Journal of Interactive Mobile Technologies, 11(3), 4-15. https://doi.org/10.3991/ijim.v11i3.5774 


\section{Authors}

Suraya Morsidi is alumna of Faculty of Social Sciences and Humanities, UTM. She had just pursued a Master Degree in Education (Educational Technology), in year 2018/2020. She also specified in Computer Science majoring in Software Engineering (Bachelor Degree). Currently, she is an Academic Coordinator at Real International \& Private School, Johor Bahru and her current interest is educational robotic training. (email: surayamorsidi@gmail.com).

Norazrena Abu Samah is currently works at the School of Education, Faculty of Social Sciences and Humanities, UTM since 2009. She received her Bachelor Science and Computer with Education (Mathematics) and $\mathrm{PhD}$ in Educational Technology from Universiti Teknologi Malaysia (UTM). Her research areas are educational technology, online learning, mobile apps for education, statistics, education for sustainable development (ESD) and environmental awareness. To date, she has received five research grants as a Principal Investigator and 24 grants as a co-investigator, including 3 international grants, namely ERASMUS+, ERASMUS and SATU-JRS. (email: norazrena@utm.my).

Khairul Anuar Abdul Rahman is currently works at the Faculty of Technical and Vocational Education, Universiti Tun Hussein Onn Malaysia (UTHM) since 2018. He received her Bachelor of Technology of Electrical Engineering with Education and $\mathrm{PhD}$ in Technical and Vocational from Universiti Teknologi Malaysia (UTM). Her research areas are alternative of teaching and learning in TVET, competency based education, and project oriented problem based learning (PoPBL). To date, he has received seven research grants (email: anuarr@uthm.edu.my).

Zakiah Mohamad Ashari is currently serving as Senior Lecturer since 2015 at the School of Education, Faculty of Sciences Social and Humanities, Universiti Teknologi Malaysia. She hold a degree in Preschool Education from Universiti Universiti Sains Malaysia and Ph.D. degree in Educational Psychology from Universiti Teknologi Malaysia. Zakiah has conducted a study on teaching and learning in preschool education, early mathematical learning, child development, module development as well as using ICT as medium in learning. (email: zakiahma@utm.my).

Nurul Farhana Jumaat is a senior lecturer from Universiti Teknologi Malaysia. She is also the editorial board for Malaysian Journal of Social Sciences and Innovative Teaching and Learning Journal. To date, she has secured 7 research grants in which she acted as Project Leader and a member of 44 other research related to online learning, learning analytics and computer-based T\&L (email: nfarhana@utm.my).

Abdul Halim Abdullah received his B.Sc. (Edu) and M.Sc. (Edu) degrees in Mathematics Education from Universiti Teknologi Malaysia (UTM). He obtained his PhD degree in Mathematics Education from Universiti Kebangsaan Malaysia (UKM). He has been serving at the School of Education, UTM since 2006. His research areas are geometry thinking, higher order thinking skills (HOTS) in mathematics and technology-aided teaching and learning in mathematics. To date, he has received nine research grants as a Principal Investigator including one from Majlis Amanah Rakyat (MARA), plus 20 grants as a co-investigator. He was also involved as a researcher in a collaborative IRU-MRUN research between the Malaysian Research Universities and Australian Innovative Research Universities (email: p-halim@utm.my).

Article submitted 2021-09-03. Resubmitted 2021-10-22. Final acceptance 2021-10-23. Final version published as submitted by the authors. 